\title{
Phylogenetic Analysis of Members of the Genus Porphyromonas and Description of Porphyromonas cangingivalis sp. nov. and Porphyromonas cansulci sp. nov.
}

\author{
M. D. COLLINS, ${ }^{1}$ DARIA N. LOVE, ${ }^{2 *}$ J. KARJALAINEN,${ }^{3}$ A. KANERVO ${ }^{3}$ B. FORSBLOM ${ }^{3}$ ANNE WILLEMS, \\ S. STUBBS, ${ }^{1}$ E. SARKIALA,${ }^{4}$ G. D. BAILEY, ${ }^{2}$ D. I. WIGNEY ${ }^{2}$ AND H. JOUSIMIES-SOMER ${ }^{3}$ \\ Department of Microbiology, AFRC Institute of Food Research, Reading Laboratory, Earley Gate, Reading RG6 2EF, \\ United Kingdom ${ }^{1}$; Department of Veterinary Pathology, University of Sydney, New South Wales 2006, \\ Australia ${ }^{2}$; and Anaerobe Reference Laboratory, National Public Health Institute, \\ 00300 Helsinki, ${ }^{3}$ and College of Veterinary Medicine, 00530 Helsinki, ${ }^{4}$ Finland
}

\begin{abstract}
The partial 16S rRNA gene sequences of representative strains of two groups of anaerobic, gram-negative, pigmented, asaccharolytic, rod-shaped bacteria isolated from subgingival plaque of dogs with naturally occurring periodontal disease were determined. A comparative analysis of the rRNA sequence data revealed that the two groups of organisms represent previously unknown lines of descent within the genus Porphyromonas. On the basis of our phylogenetic findings and the phenotypic distinctiveness of the organisms, two new species, Porphyromonas cangingivalis and Porphyromonas cansulci, are proposed.
\end{abstract}

Periodontal disease is a significant oral problem of dogs and is characterized by halitosis, gingival inflammation, increased periodontal pocket depth, and alveolar bone loss with resulting loosening and eventual loss of teeth. During our investigation of the subgingival flora of 16 family-owned dogs with naturally occurring periodontitis, a large number of strictly anaerobic, nonsporing, gram-negative, asaccharolytic, rod-shaped bacteria were isolated $(10,21,22)$. On the basis of the results of morphological, biochemical, and API ZYM enzyme analyses we placed several groups of these organisms in the genus Porphyromonas. One group, which comprised 12 of the 259 phenotypically characterized isolates, was recently described as a new species (Porphyromonas canoris) (14). Two other groups were divided on the basis of the results of phenotypic and DNA-DNA hybridization analyses (unpublished data) from currently recognized species in the genus. One group comprised 88 of the phenotypically characterized isolates and was the single most prevalent group in the study, while the other group was distinct but less prevalent, comprising 6 of the 259 strains (10). In this study, the partial 16S rRNA gene sequences of representative strains of these two groups were determined. On the basis of the results of a comparative sequence analysis and the phenotypic distinctiveness of the groups, two new species, Porphyromonas cangingivalis and Porphyromonas cansulci, are described.

\section{MATERIALS AND METHODS}

Bacterial strains. Of the 88 strains described previously (10) as members of group C, 6 were examined in more detail in this study. These strains were AHN (Anaerobe Reference Laboratory, Helsinki Collection) 3421 (= VPB [Veterinary Pathology and Bacteriology Collection] 4871), AHN 3582 (= VPB 4872), AHN 4309 $\left(=\right.$ VPB $\left.4874^{\mathrm{T}}\right)(\mathrm{T}=$ type strain $)$, AHN $3592(=$ VPB 4946), AHN 4461 (=VPB 4945), and AHN 4811 (= VPB 4940) and originated from five diseased periodontal sites and one healthy periodontal site in six dogs. Five of the six strains

\footnotetext{
* Corresponding author. Mailing address: Department of Veterinary Pathology, Sydney University, New South Wales 2006, Australia. Phone: 61-2-692-2454. Fax: 61-2-552-6526. Electronic mail address: suvp00@angis.su.oz.au.
}

described in the previous study as members of group $\mathrm{C} 1$ were also examined; these strains were AHN $4364^{\mathrm{T}}$ (=VPB $4875^{\mathrm{T}}$ ), AHN 4387 (= VPB 4876), AHN 4706 (= VPB 4877), AHN 3929 (= VPB 4943), and AHN 3908 (= VPB 4942) and originated from three diseased periodontal sites and two healthy periodontal sites in four dogs. Other strains included in the study for comparison included feline strains Porphyromonas salivosa NCTC $11632^{\mathrm{T}}$, Porphyromonas circumdentaria NCTC $12469^{\mathrm{T}}$, and Porphyromonas gingivalis VPB 3492; canine strain P. canoris NCTC $12835^{\mathrm{T}}$; human strains Porphyromonas endodontalis ATCC $35406^{\mathrm{T}}, P$. gingivalis ATCC $33277^{\mathrm{T}}$, Porphyromonas asaccharolytica ATCC $25260^{\mathrm{T}}$, and Bacteroides levii ATCC $29147^{\mathrm{T}}$; and monkey strain Bacteroides macacae ATCC $33141^{\mathrm{T}}$.

Growth conditions and biochemical methods. The general methods used for growth and for morphological and biochemical characterization tests have been described previously (1, 11-13). The cells used for cellular fatty acid and allozyme assays were grown anaerobically for 3 days on $5 \%$ ( $\mathrm{vol} / \mathrm{vol}$ ) sheep blood agar plates (blood agar base no. 2; Oxoid, Ltd., Basingstoke, England) supplemented with additional heminmenadione, formate-fumarate (7), and $1.5 \%$ (wt/vol) proteose peptone (Difco Laboratories, Detroit, Mich.) in the presence of a streak of Staphylococcus epidermidis (used to enhance the growth rate and the pigmentation of colonies).

$16 S$ rRNA gene sequence determination and sequence analysis. The partial 16S rRNA gene sequences of strains VPB 4872 , VPB $4874^{\mathrm{T}}$, VPB $4875^{\mathrm{T}}$, and VPB 4876 were determined by direct PCR sequencing. DNA was amplified in two overlapping fragments by using four $16 \mathrm{~S}$ rRNA universal primers $\left(5^{\prime}\right.$ to $3^{\prime}$ ) in the following two combinations: pA (AGAGTTT GATCCTGGCTCAG) and pE* (CCGTCAATTCCTTTGAG TTT); and pD (CAGCAGCCGCGGTAATAC) and pH (AA GGAGGTGATCCAGCCGCA). PCR amplification was performed by using a thermal cycler (Biometra, Maidstone, United Kingdom). Each reaction mixture contained $10 \mu \mathrm{l}$ of $10 \times$ buffer $\left(50 \mathrm{mM} \mathrm{KCl}, 10 \mathrm{mM}\right.$ Tris- $\mathrm{HCl}, 15 \mathrm{mM} \mathrm{MgCl}_{2}, 10 \%$ [ $\mathrm{vol} / \mathrm{vol}$ ] glycerol), $10 \mu \mathrm{l}$ of a deoxyribonucleotide mixture $(1.25$ $\mathrm{mM}$ each $), 1 \mu \mathrm{l}$ of each primer $(200 \mathrm{ng} / \mu \mathrm{l}), 1 \mu \mathrm{l}$ of purified DNA (10 ng/ $\mu \mathrm{l})$, and enough sterile distilled water to bring the volume to $100 \mu \mathrm{l}$. The mixture was denatured at $94^{\circ} \mathrm{C}$ for $3 \mathrm{~min}$ before we added $1 \mu \mathrm{l}(1 \mathrm{U})$ of Taq polymerase (Amersham 
International, Amersham, United Kingdom) and $50 \mu \mathrm{l}$ of sterile mineral oil. The temperature profile consisted of 25 cycles of denaturation at $92^{\circ} \mathrm{C}$ for $2 \mathrm{~min}$, primer annealing at $55^{\circ} \mathrm{C}$ for $1 \mathrm{~min}$, and extension at $72^{\circ} \mathrm{C}$ for $1.5 \mathrm{~min}$. In the last cycle, the elongation step at $72^{\circ} \mathrm{C}$ was extended to $5 \mathrm{~min}$. PCR products were purified by using a MagicDNA system (Promega, Southampton, United Kingdom) according to the manufacturer's instructions. Direct sequencing of 16S rRNA genes was carried out with a Sequenase version 2.0 sequencing kit (Cambridge Biosciences, Ltd., Cambridge, United Kingdom) and ${ }^{35}$ S-labeled dATP, using the method of Hutson et al. (8).

The 16S rRNA gene sequences which we determined were aligned and compared (3) with the 16S rRNA gene sequences of other gram-negative bacteria available in EMBL Data Library and the Ribosomal RNA Data Base. Levels of sequence similarity and nucleotide substitution rates $\left(K_{\text {nuc }}\right.$ values) were calculated and used to produce an unrooted phylogenetic tree by the neighbor-joining method (19). The stability of relationships was assessed by bootstrapping (4), using the SEQBOOT, DNADIST, NEIGHBOR, and CONSENSE programs of the PHYLIP package (5).

DNA hybridization assays. The cell growth conditions used have been described previously (11-13), and DNA extraction was performed essentially by the method of Marmur and Doty (15).

$\mathbf{G}+\mathbf{C}$ contents of DNAs. Thermal melting points were used to determine the guanine-plus-cytosine $(G+C)$ contents of DNA preparations as described previously (11). Values were determined for each organism on three separate occasions. Escherichia coli b DNA (Sigma) was included as a standard in each run.

Preparation of labeled nucleic acids. Fragmented, denatured DNA was labeled with ${ }^{125} \mathrm{I}$ by a variation of the thallium chloride method $(23,27)$.

DNA hybridization methods. DNA was fragmented by sonication followed by heating in a boiling water bath for $5 \mathrm{~min}$, and the concentration was adjusted to $0.4 \mathrm{mg} / \mathrm{ml}$. DNA hybridization values were determined by using an $\mathrm{S} 1$ nuclease procedure described previously (9).

Allozyme electrophoresis. Cells grown for 3 to 5 days were harvested from plates with a bent glass rod, suspended in sterile water and stored at $-140^{\circ} \mathrm{C}$ until they were used. Electrophoresis on Cellogel (Chemetron, Milan, Italy) was carried out with supernatant fluids from sonicated cell preparations (Wellcome tube 5 density) by using the method of Richardson et al. (18) to determine the presence of characteristic metabolic pathway enzymes. End points of reactions were read no later than $15 \mathrm{~min}$ after the reaction mixture was added to the gel.

Preparation and analysis of fatty acids of whole bacterial cells. Cells were harvested from plates after 3 days with a glass rod and were treated immediately essentially as described by Ghanem et al. (6). A model HP 5890 Series II gas chromatograph and a model HP 7673 injector (Hewlett Packard) were used for detection. The organic phase was chromatographed on a fused silica capillary column (catalog no. 19091J-102; Hewlett Packard). The column running conditions were the conditions described by Ghanem et al. (6). For fatty acid identification a bacterial acid methyl ester CP mixture (catalog no. 4-7080; Supelco, Bellefonte, Pa.) was chromatographed at the beginning of each run and after each four samples. Equivalent chain lengths were calculated as described in the MIS system instructions (MIDI, Newark, Del.).

Spectrophotometric determination of dehydrogenase activity. Portions of the preparations used for the allozyme electrophoresis analysis of strains VPB $4874^{\mathrm{T}}$ and VPB $4875^{\mathrm{T}}$ were assayed by a standard method used for glucose-6-phosphate dehydrogenase incorporating maleimide (2). The 6-phosphogluconate dehydrogenase assay was performed like the glucose-6-phosphate dehydrogenase assay except that maleimide was omitted from the assay mixture and 6-phosphogluconate was used as the substrate. For these assays Bacteroides fragilis ATCC $25285^{\mathrm{T}}$ was used as a species that had known dehydrogenase activity $(25,26)$. The activity values reported below are the averages of three separate assays per preparation. A protein assay (Bio-Rad, Richmond, Calif.) was used as recommended by the manufacturer to determine the protein concentration of each preparation.

Nucleotide sequence accession numbers. The 16S rRNA gene sequences of strains VPB $4874^{\mathrm{T}}$ and VPB $4875^{\mathrm{T}}$ have been deposited in the GenBank (EMBL) database under accession numbers $\mathrm{X} 76259$ and X76260, respectively.

\section{RESULTS AND DISCUSSION}

The 16S rRNA genes of strains VPB $4874^{\mathrm{T}}$ (group C) and VPB $4875^{\mathrm{T}}$ (group C1) were amplified by the PCR by using primers targeted to conserved regions, and their nucleotide sequences were determined directly. The sequencing strategy used resulted in determination of more than 1,480 nucleotides for each gene product, representing approximately $96 \%$ of the total primary rRNA structure. The two sequences were subjected to a pairwise analysis and exhibited $89.5 \%$ sequence similarity. The sequences of a short fragment (approximately positions 30 to 500 , which included diagnostic variable regions V1 to V3) of the 16S rRNA genes of two other representatives of groups C and C1 (group C strain VPB 4872 and group C1 strain VPB 4876) were also determined. The sequences of strains VPB 4872 and VPB 4876 were identical to those of VPB $4874^{\mathrm{T}}$ and VPB $4875^{\mathrm{T}}$, respectively, confirming the genotypic homogeneity of each group.

The derived 16S rRNA sequences of strains VPB $4874^{\mathrm{T}}$ and VPB $4875^{\mathrm{T}}$ were aligned and compared with the sequences of other gram-negative bacteria retrieved from EMBL Data Library and the Ribosomal RNA Data Base Project (16). A matrix of representative sequence similarity values is shown in Table 1. The $16 \mathrm{~S}$ rRNAs of the two unidentified dog isolates exhibited the highest levels of sequence similarity (approximately 85 to $91 \%$ ) with species of the genus Porphyromonas and some "Bacteroides" spp. known to be members of the genus Porphyromonas (viz. B. levii and B. macacae). Lower levels of sequence relatedness were observed with Bacteroides strains (approximately 81 to 84\%), Prevotella strains (approximately 77 to $80 \%$ ), and Rikenella microfusus (approximately $83 \%$ ) (Table 1). A tree constructed by the neighbor-joining method showing the phylogenetic relationships of strains VPB $4874^{\mathrm{T}}$ and VPB $4875^{\mathrm{T}}$ is shown in Fig. 1. This tree confirmed that these strains should be placed in the genus Porphyromonas. Both the distance values and the treeing program clearly showed that the two previously undescribed bacteria are members of quite separate lines within the genus Porphyromonas. Interestingly, bootstrap calculations revealed a significant (albeit distant) relationship between VPB $4874^{\mathrm{T}}$ (group C) and $P$. canoris. In contrast, VPB $4875^{\mathrm{T}}$ (group $\mathrm{C} 1$ ) did not exhibit specific affinity to any other Porphyromonas species (bootstrap value, 65) (Fig. 1).

Our phylogenetic data showed that members of groups $\mathrm{C}$ and $\mathrm{Cl}$ of Karjalainen et al. (10) (along with the recently described species $P$. canoris [14]) are distinct from any of the previously described species of the genus Porphyromonas. The presence of 13-methyltetradecanoic acid (iso- $\mathrm{C}_{15: 0}$ ) as the major long-chain cellular fatty acid (Table 2 ) is consistent with 
TABLE 1. Levels of 16S rRNA sequence similarity for Porphyromonas spp. and some representatives of the genera Bacteroides, Prevotella, and Rikenella

\begin{tabular}{|c|c|c|c|c|c|c|c|c|c|c|c|c|c|c|c|c|}
\hline \multirow[b]{2}{*}{ Taxon } & \multicolumn{16}{|c|}{$\%$ of $16 \mathrm{~S}$ rRNA similarity to: } \\
\hline & 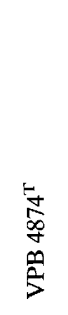 & 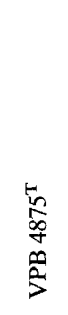 & 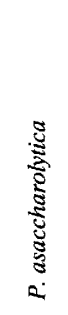 & 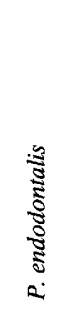 & 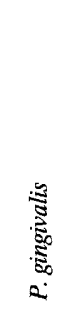 & 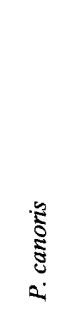 & 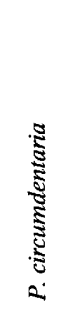 & $\frac{:}{2}$ & 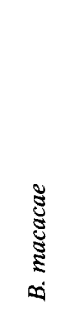 & 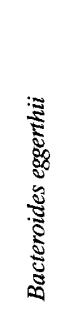 & 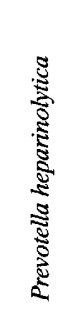 & 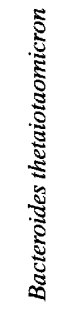 & 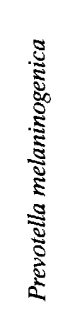 & 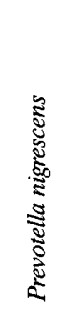 & 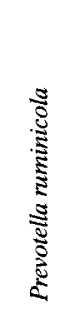 & 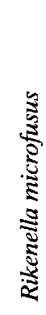 \\
\hline \multicolumn{17}{|l|}{ VPB $4874^{\mathrm{T}}$} \\
\hline VPB $4875^{\mathrm{T}}$ & 89.5 & & & & & & & & & & & & & & & \\
\hline P. asaccharolytica & 85.9 & 85.1 & & & & & & & & & & & & & & \\
\hline P. endodontalis & 88.4 & 87.2 & 88.1 & & & & & & & & & & & & & \\
\hline$P$. gingivalis & 88.9 & 89.4 & 85.6 & 87.8 & & & & & & & & & & & & \\
\hline P. canoris & 91.2 & 89.3 & 84.4 & 85.6 & 89.2 & & & & & & & & & & & \\
\hline P. circumdentaria & 87.5 & 86.3 & 87.6 & 93.8 & 86.7 & 85.5 & & & & & & & & & & \\
\hline B. levii & 91.2 & 87.5 & 84.9 & 86.7 & 86.5 & 88.4 & 86.2 & & & & & & & & & \\
\hline B. macacae ${ }^{a}$ & 88.3 & 87.9 & 85.4 & 87.6 & 88.4 & 87.8 & 87.9 & 87.2 & & & & & & & & \\
\hline Bacteroides eggerthii & 83.8 & 83.0 & 82.2 & 83.8 & 84.7 & 82.9 & 83.8 & 85.0 & 83.6 & & & & & & & \\
\hline Prevotella heparinolytica & 83.2 & 81.3 & 80.5 & 82.2 & 83.7 & 81.1 & 83.1 & 83.2 & 82.8 & 92.9 & & & & & & \\
\hline Bacteroides thetaiotaomicron & 83.6 & 82.3 & 82.6 & 83.2 & 83.9 & 83.6 & 84.1 & 84.8 & 84.6 & 93.6 & 91.2 & & & & & \\
\hline Prevotella melaninogenica & 80.1 & 79.4 & 79.6 & 80.3 & 80.2 & 78.6 & 80.0 & 81.0 & 79.5 & 85.9 & 85.4 & 85.1 & & & & \\
\hline Prevotella nigrescens & 78.5 & 78.7 & 78.4 & 79.5 & 80.2 & 77.2 & 78.5 & 79.3 & 78.9 & 84.5 & 84.9 & 83.6 & 91.7 & & & \\
\hline Prevotella ruminicola & 79.4 & 77.2 & 78.8 & 79.7 & 80.1 & 78.0 & 80.6 & 79.1 & 79.3 & 85.8 & 84.3 & 84.6 & 89.5 & 87.0 & & \\
\hline R. microfusus & 82.8 & 82.6 & 80.8 & 82.7 & 82.2 & 81.4 & 83.3 & 82.9 & 83.2 & 82.7 & 81.1 & 80.7 & 80.0 & 80.2 & 80.8 & \\
\hline
\end{tabular}

${ }^{a} B$. macacae and $P$. salivosa exhibit approximately $99.3 \%$ sequence similarity (17).

placement of these organisms in the genus Porphyromonas. The results of allozyme electrophoresis of four metabolic enzymes showed, however, that while malate and glutamate dehydrogenases were present in all members of each group tested, as required for members of the genus Porphyromonas (24), glucose-6-phosphate dehydrogenase and 6-phosphogluconate dehydrogenase were present in group $\mathrm{C}$ strains but were absent in group $\mathrm{C} 1$ strains. In a spectrophotometric analysis on the results obtained for VPB $4874^{\mathrm{T}}$ we detected an average of $543 \mathrm{nmol}$ of glucose-6-phosphate dehydrogenase per mg of protein per min (compared with $96.2 \mathrm{nmol} \mathrm{mg} \mathrm{of}$ protein $\left.{ }^{-1} \mathrm{~min}\right)^{-1}$ for $B$. fragilis) and an average of $336 \mathrm{nmol}$ of 6-phosphogluconate dehydrogenase per $\mathrm{mg}$ of protein per min (compared with $35.9 \mathrm{nmol} \mathrm{mg} \mathrm{of} \mathrm{protein}{ }^{-1} \min ^{-1}$ for $B$. fragilis). The results obtained for members of group $\mathrm{C}$ are at variance with the results obtained for members of the genus isolated from humans but are consistent with the results obtained for $P$. salivosa and $P$. canoris (14). Table 3 shows the results of biochemical and enzyme reactions which may be helpful for differentiating the species within the genus Porphyromonas.

In view of the enzymatic diversity among Porphyromonas spp. observed, it could be suggested that $P$. canoris and the unidentified group $\mathrm{C}$ organisms are not genuine members of the genus Porphyromonas. In this context, it is worth noting that the genus Porphyromonas is phylogenetically deep, with members exhibiting levels of $16 \mathrm{~S}$ rRNA sequence divergence of up to $15 \%$ (Table 1). This value is significantly greater than the maximum level of divergence within the genus Bacteroides (approximately 9\%) and marginally greater than the maximum level of divergence within the genus Prevotella (approximately $12 \%$ ). It could be argued that these data indicate that the members of the genus Porphyromonas are phylogenetically too heterogeneous to be placed in a single genus. However, tree topology considerations indicate that there can be no obvious phylogenetic division of the porphyromonads without a major proliferation of other genera. Some Porphyromonas species exhibit close relationships (e.g. $P$. asaccharolytica, $P$. circumdentaria, and $P$. endodontalis [bootstrap significance, 94]; $P$. canoris and group C [bootstrap significance, 95]), but other species exhibit no significant levels of affinity with other members of the genus. Consequently, restriction of the genus Porphyromonas to the type species ( $P$. asaccharolytica) and $P$. endodontalis would mean that separate genera would have to be created for $P$. gingivalis, $B$. levii, $B$. macacae, group $\mathrm{C} 1$, and the $P$. canoris and the group $C$ taxon. The genus Porphyromonas (24) is now widely used and accepted by members of the scientific community. In our opinion, subdivision of the genus would serve no useful purpose and would create unnecessary nomenclatural confusion. On the basis of the treeing program results there is no doubt that porphyromonads (including $B$. levii, $B$. macacae, and groups $\mathrm{C}$ and $\mathrm{C} 1$ ) form a natural, albeit deep, phylogenetic group (bootstrap significance, 99) (Fig. 1). We therefore suggest that the genus Porphyromonas should be retained but that its description should take into account the production of the hexose monophosphate shunt-pentose phosphate pathway enzymes (viz., glucose-6-phosphate dehydrogenase, 6-phosphogluconate dehydrogenase) by some species. Furthermore, we propose that unidentified groups $\mathrm{C}$ and $\mathrm{C} 1$ obtained from subgingival plaque of dogs should be designated two new species, Porphyromonas cangingivalis and Porphyromonas cansulci, respectively.

The following descriptions are based on results of this study and the study of Karjalainen et al. (10).

Description of Porphyromonas cangingivalis sp. nov. (group C). Porphyromonas cangingivalis (can.gin.gi.val'is. L. n. canis, dog; L. n. gingiva gum; L. gen. n. cangingivalis, of the gums of dogs). Cells are anaerobic, nonsporing, nonmotile, gram- 


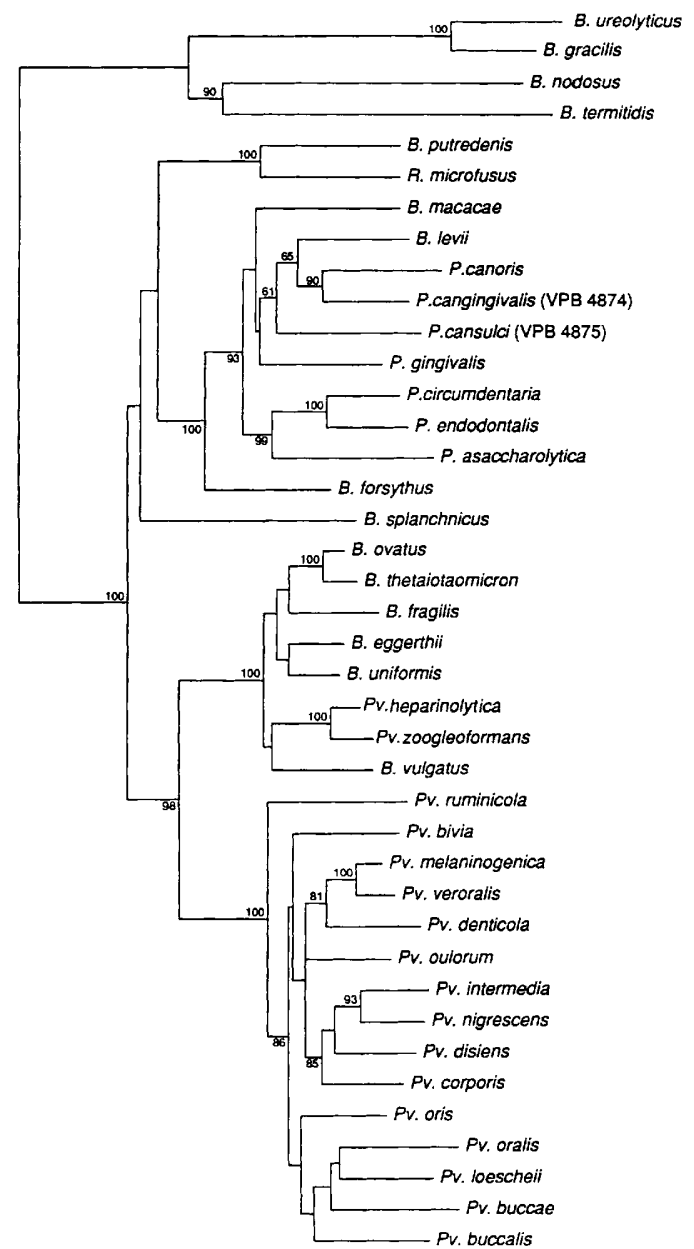

FIG. 1. Unrooted tree constructed by using the neighbor-joining method, showing the phylogenetic interrelationships of $P$. cangingivalis, $P$. cansulci, and some other obligately anaerobic gram-negative taxa. The numbers indicate the percentages of occurrence in bootstrapped trees. Values of $>90 \%$ are considered significant. Abbreviations: B., Bacteroides; P., Porphyromonas; Pv., Prevotella; R., Rikenella.

negative rods or coccoids. In cooked-meat-carbohydrate medium (12) and on $5 \%(\mathrm{vol} / \mathrm{vol})$ sheep blood agar plates, cells are 0.3 to 0.6 by 0.8 to $1.5 \mu \mathrm{m}$ and occur singly and in clumps; occasionally filaments up to $16 \mu \mathrm{m}$ long are observed. On sheep blood agar plates, surface colonies after $48 \mathrm{~h}$ are $1 \mathrm{~mm}$ in diameter, circular, dome shaped, nonhemolytic, and smooth. Colonies are poorly pigmented and cream to $\tan$ after 3 to 5 days; by 10 days they are light brown to chestnut. On laked rabbit or sheep blood, colonies are light brown to greenish brown after 5 days and black after 12 days of incubation. On egg yolk agar, colonies are yellow or orange. The colonies of strains VPB 4872 and VPB 4946 indent the agar by day 5 , and after 5 days on sheep blood agar the colonies of VPB 4872 , VPB $4874^{\mathrm{T}}$, and VPB 4946 exhibit peripheral flattening and have a roughened and dry surface appearance. Colonies do not fluorescence under UV light (265 and $366 \mathrm{~nm}$ ) after 3, 7, or 13 days. Vitamin $\mathrm{K}$ and hemin are required for growth. After incubation for 5 days the $\mathrm{pH}$ values in media containing carbohydrates (uninoculated $\mathrm{pH}, 6.8$ to 7.4 ) generally range from 6.3 to 6.5 . Carbohydrate fermentation is not detected with adonitol, cellobiose, fructose, glucose, glycogen, inositol, lactose, maltose, mannitol, rhamnose, salicin, starch, sucrose,

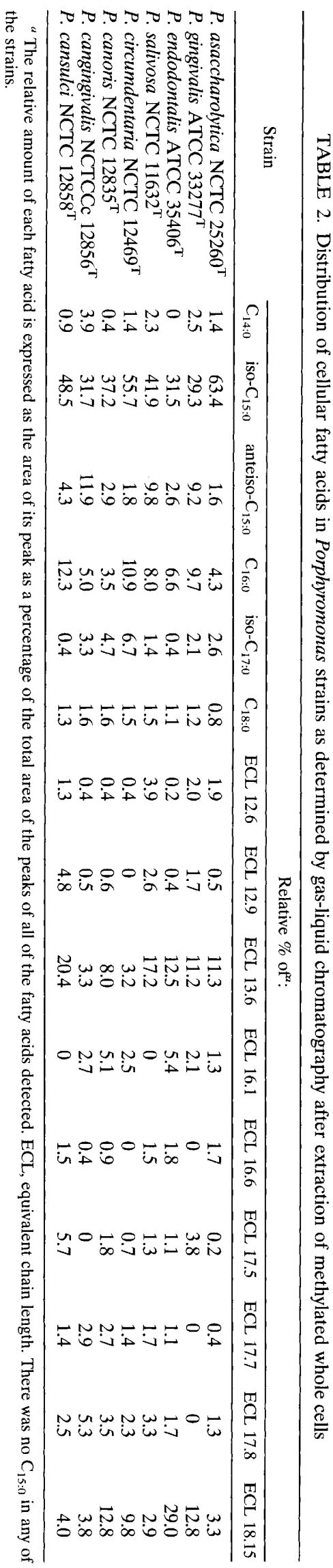


TABLE 3. Comparison of canine strains of $P$. cangingivalis sp. nov. and $P$. cansulci sp. nov. with feline and human members of the genus Porphyromonas and the closely related organisms $B$. levii and $B$. macacae

\begin{tabular}{|c|c|c|c|c|c|c|c|c|c|c|c|c|}
\hline Strain & 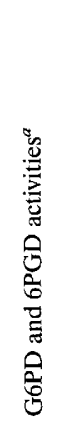 & 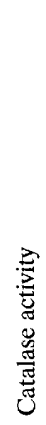 & 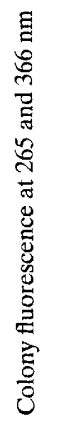 & 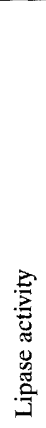 & 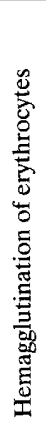 & 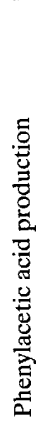 & 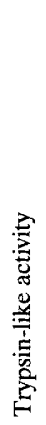 & 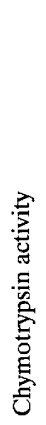 & 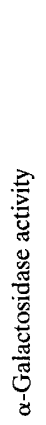 & 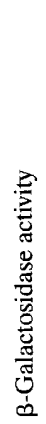 & 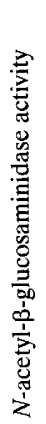 & 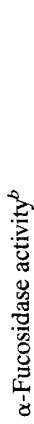 \\
\hline P. asaccharolytica ATCC $25260^{\mathrm{T}}$ & $-^{c}$ & - & + & - & - & - & - & - & - & - & - & + \\
\hline P. endodontalis ATCC $35406^{\mathrm{T}}$ & - & -- & + & - & - & - & - & - & - & - & - & - \\
\hline$P$. gingivalis ATCC $33277^{\mathrm{T}}$ & - & - & - & - & + & + & + & - & - & - & + & - \\
\hline P. gingivalis VPB 3492 & - & + & - & - & + & + & + & - & - & - & + & - \\
\hline P. salivosa NCTC $11632^{\mathrm{T}}$ & + & + & $\ldots d$ & + & - & + & + & + & + & - & + & - \\
\hline P. circumdentaria NCTC $12469^{\mathrm{T}}$ & - & + & + & - & - & + & - & - & - & - & - & - \\
\hline P. canoris NCTC $12835^{\mathrm{T}}$ & + & + & + & $-e$ & - & - & - & + & - & + & + & - \\
\hline P. cangingivalis NCTC $12856^{\mathrm{T}}$ & + & + & - & - & - & - & - & + & - & - & - & - \\
\hline P. cansulci NCTC $12858^{\mathrm{T}}$ & - & + & + & $-e$ & - & + & - & - & - & - & - & - \\
\hline B. levii ATCC $29147^{\mathrm{T} f}$ & ND & - & +8 & - & - & - & - & + & - & + & + & - \\
\hline B. macacae ACTT $33141^{\mathrm{T}}$ & ND & + & + & - & - & + & + & + & + & - & + & - \\
\hline
\end{tabular}

${ }^{a} \mathrm{G} 6 \mathrm{PD}$, glucose-6-phosphate dehydrogenase; 6PGD, 6-phosphogluconate dehydrogenase. These enzyme activities were determined by alloenzyme electrophoresis and/or spectrophotometry.

${ }^{b}$ Detected by the API ZYM method (1)

$c-$, no activity; + , activity; ND, not determined.

${ }^{d}$ The type strain does not fluoresce; other strains may fluoresce (11).

${ }^{e}$ A yellowish orange pigment is produced on egg yolk agar.

${ }^{f} B$. levii is indole negative; all other Bacteroides species are indole positive.

${ }^{g}$ Human clinical isolates that most closely resemble B. levii may fluoresce weakly or not at all.

trehalose, or xylose. Ammonia is produced in cooked-meat medium (12).

The short-chain fatty acids produced in cooked-meat medium are acetate (average, $31.4 \mu \mathrm{mol} / \mathrm{ml}$ ), propionate (average, $5.1 \mu \mathrm{mol} / \mathrm{ml}$ ), isobutyrate (average, $0.6 \mu \mathrm{mol} / \mathrm{ml}$ ), butyrate (average, $16.2 \mu \mathrm{mol} / \mathrm{ml}$ ), and isovalerate (average, $3.5 \mu \mathrm{mol} /$ $\mathrm{ml}$ ). No succinate or phenylacetic acid is detected. Neither lactate nor threonine is converted to propionate, and pyruvate is not utilized. Strains are catalase positive and acid and alkaline phosphatase positive but do not exhibit trypsin-like activity or produce lipase or lecithinase. All of the strains which we studied and $69 \%$ of the strains described previously (10) produce chymotrypsin weakly but are $N$-acetyl- $\beta$-glucosaminidase, $\beta$-galactosidase, $\alpha$-galactosidase, and $\alpha$-fucosidase negative. Cells from colonies do not hemagglutinate sheep erythrocytes. Strains are indole positive but do not reduce nitrate; urea is not split, and esculin is not hydrolyzed. Malate, glutamate, glucose-6-phosphate, and 6-phosphogluconate dehydrogenases are present. The predominant cellular fatty acid is 13-methyltetradecanoic acid (iso- $\mathrm{C}_{15: 0}$ acid); smaller amounts of other acids are also present (Table 2).

All of the strains which we studied except VPB 4871 are susceptible to penicillin $(2 \mathrm{U} / \mathrm{ml})$, amoxicillin $(2.5 \mu \mathrm{g} / \mathrm{ml})$, carbenicillin $(100 \mu \mathrm{g} / \mathrm{ml})$, and erythromycin $(3 \mu \mathrm{g} / \mathrm{ml})$. Of the 20 group $C$ strains tested $(20), 7(35 \%)$ produce $\beta$-lactamase, with penicillin G MICs ranging from 4.0 to $32 \mu \mathrm{g} / \mathrm{ml}$.

The $\mathrm{G}+\mathrm{C}$ content of the DNA is $55 \mathrm{~mol} \%$, as determined by the thermal denaturation method (15). The average level of intraspecies DNA-DNA hybridization is $90 \%$. Strain VPB $4874^{\mathrm{T}}\left(=\right.$ NCTC $\left.12856^{\mathrm{T}}\right)$ exhibits $11 \%$ DNA-DNA hybridization with $P$. cansulci NCTC $12858^{\mathrm{T}},<0.1 \%$ hybridization with
$P$. gingivalis ATCC $33277^{\mathrm{T}}, 3 \%$ hybridization with $P$. salivosa NCTC $11632^{\mathrm{T}}, 8 \%$ hybridization with cat strains of $P$. gingivalis, 3\% hybridization with $P$. endodontalis ATCC $35406^{\mathrm{T}}$, $<0.7 \%$ hybridization with $P$. circumdentaria, $0.6 \%$ hybridization with $P$. asaccharolytica ATCC $25260^{\mathrm{T}}, 3 \%$ hybridization with $B$. levii ATCC $29147^{\mathrm{T}},<0.1 \%$ hybridization with $P$. canoris NCTC $12835^{\mathrm{T}}$, and $1 \%$ hybridization with $B$. macacae ATCC $33141^{\mathrm{T}}$.

All strains were isolated from diseased or healthy periodontal pockets of dogs with naturally occurring periodontitis.

The type strain is NCTC 12856 (= VPB 4874).

Description of Porphyromonas cansulci sp. nov. (group C1). Porphyromonas cansulci (can.sul' ci. L. n. canis, dog; L. gen. n. sulci, of a furrow; cansulci, referring to the habitat in the mouths of dogs). Cells are anaerobic, nonsporing, nonmotile, gram-negative rods or coccoids. In cooked-meat-carbohydrate medium and on sheep blood agar plates, cells are 0.3 to 0.6 by 0.8 to $1.5 \mu \mathrm{m}$ and occur singly and in groups. On sheep blood agar plates, surface colonies after 3 days are 1 to $2 \mathrm{~mm}$ in diameter, circular, dome shaped, and smooth. Colonies are black to brown after 5 days. On egg yolk agar, colonies are yellow or orange. Colonies produce brick red fluorescence under UV light ( 265 and $366 \mathrm{~nm}$ ) by day 3. On laked rabbit or sheep blood, colonies are light brown after 2 days and black after 5 days of incubation. Vitamin $\mathrm{K}$ and hemin are required for growth. After incubation for 5 days, the $\mathrm{pH}$ values in media containing carbohydrates (uninoculated $\mathrm{pH}, 6.8$ to 7.4 ) generally range from 6.3 to 6.5 . Carbohydrate fermentation is not detected with adonitol, cellobiose, fructose, glucose, glycogen, inositol, lactose, maltose, mannitol, rhamnose, salicin, starch, 
sucrose, trehalose, or xylose. Ammonia is produced from cooked-meat medium.

The short-chain fatty acids produced in cooked-meat medium are acetate (average, $31.9 \mu \mathrm{mol} / \mathrm{ml}$ ), propionate (average, $30.1 \mu \mathrm{mol} / \mathrm{ml}$ ), isobutyrate (average, $7.6 \mu \mathrm{mol} / \mathrm{ml}$ ), butyrate (average, $34.3 \mu \mathrm{mol} / \mathrm{ml}$ ), isovalerate (average, 20.8 $\mu \mathrm{mol} / \mathrm{ml}$ ), succinate (average, $18.5 \mu \mathrm{mol} / \mathrm{ml}$ ), and phenylacetic acid (average, $2.7 \mu \mathrm{mol} / \mathrm{ml}$ ). Neither lactate nor threonine is converted to propionate, and pyruvate is not utilized. Strains are catalase positive and are acid and alkaline phosphatase positive but do not exhibit trypsin-like activity or produce lipase or lecithinase. They do not produce chymotrypsin. $N$-acetyl- $\beta$-glucosaminidase, $\beta$-galactosidase, $\alpha$-galactosidase, or $\alpha$-fucosidase. Sheep erythrocytes are not hemagglutinated. Cultures produce indole, but nitrate is not reduced, urea is not split, and esculin is not hydrolyzed. Malate and glutamate dehydrogenases are present; glucose-6-phosphate and 6-phosphogluconate dehydrogenases are absent. The predominant cellular fatty acid is 13-methyltetradecanoic acid (iso- $C_{15.0}$ acid); smaller amounts of other acids are also present (Table 2).

Strains are susceptible to penicillin $(2 \mathrm{U} / \mathrm{ml})$, amoxicillin $(2.5$ $\mu \mathrm{g} / \mathrm{ml})$, carbenicillin $(100 \mu \mathrm{g} / \mathrm{ml})$, and erythromycin $(3 \mu \mathrm{g} / \mathrm{ml})$. $\beta$-Lactamase-producing strains have not been detected among group $\mathrm{C} 1$ isolates $(20)$.

The $\mathrm{G}+\mathrm{C}$ content of the DNA is 49 to $51 \mathrm{~mol} \%$, as determined by the thermal denaturation method (15). The average level of intraspecies DNA-DNA hybridization is $97 \%$. Strain VPB $4875^{\mathrm{T}}\left(=\right.$ NCTC $\left.12858^{\mathrm{T}}\right)$ exhibits $7 \%$ DNA-DNA hybridization with $P$. cangingivalis, $<0.1 \%$ hybridization with $P$. canoris NCTC $12835^{\mathrm{T}},<0.1 \%$ hybridization with $P$. gingivalis ATCC $33277^{\mathrm{T}}, 0.6 \%$ hybridization with $P$. salivosa NCTC $11632^{\mathrm{T}},<0.1 \%$ hybridization with cat strains of $P$. gingivalis, $1 \%$ hybridization with $P$. endodontalis ATCC $35406^{\mathrm{T}},<0.1 \%$ hybridization with $P$. circumdentaria, $1 \%$ hybridization with $P$. asaccharolytica ATCC $25260^{\mathrm{T}}, 0.6 \%$ hybridization with $B$. levii ATCC $29147^{\mathrm{T}}$, and $<0.1 \%$ hybridization with $B$. macacae ATCC $33141^{\mathrm{T}}$.

All strains were isolated from diseased or healthy periodontal pockets of dogs with naturally occurring periodontitis.

The type strain is NCTC 12858 (= VPB 4875).

Characteristics which distinguish $P$. cangingivalis sp. nov. and $P$. cansulci sp. nov. from other members of the genus Porphyromonas and related taxa are summarized in Table 3.

\section{ACKNOWLEDGMENTS}

This work was supported in part by the Australian Research Council.

Prereduced and other bacteriological media were prepared by $\mathbf{L}$. Patoka and F. Taeker.

\section{REFERENCES}

1. Collings, S., and D. N. Love. 1992. Further studies on some physical and biochemical characteristics of asaccharolytic pigmented Bacteroides of feline origin. J. Appl. Bacteriol. 72:529-535.

2. Deutsch, J. 1983. Glucose-6-phosphate dehydrogenase, p. 190 197. In H. V. Bergmeyer (ed.), Methods in enzymatic analysis, vol. 3, 3rd ed. Verlag Chemie, Weinheim, Germany.

3. Devereux, J., P. Haeberli, and O. Smithies. 1984. A comprehensive set of sequence analysis programs for the VAX. Nucleic Acids Res. 12:387-395.

4. Felsenstein, J. 1985. Confidence limits on phylogenies: an approach using the bootstrap. Evolution 39:783-791.

5. Felsenstein, J. 1989. PHYLIP-phylogeny inference package (version 3.2). Cladistics 5:164-166.

6. Ghanem, F. M., A. C. Ridpath, W. E. C. Moore, and L. V. H.
Moore. 1991. Identification of Clostridium botulinum, Clostridium argentinense, and related organisms by cellular fatty acid analysis. J. Clin. Microbiol. 29:1114-1124.

7. Holdeman, L. V., E. P. Cato, and W. E. C. Moore. 1977. Anaerobe laboratory manual, 4th ed. Virginia Polytechnic Institute and State University, Blacksburg.

8. Hutson, R. A., D. E. Thompson, and M. D. Collins. 1993. Genetic interrelationships of saccharolytic Clostridium botulinum types B, $\mathrm{E}$, and $\mathrm{F}$ and related clostridia as revealed by small-subunit rRNA gene sequences. FEMS Microbiol. Lett. 108:103-110.

9. Johnson, J. L. 1985. DNA reassociation and RNA hybridization of bacterial nucleic acids. Methods Microbiol. 18:33-74.

10. Karjalainen, J., A. Kanervo, M.-L. Vaisanen, B. Forsblom, E. Sarkiala, and H. Jousimies-Somer. 1993. Porphyromonas-like gram-negative rods in naturally occurring periodontitis in dogs. FEMS Immunol. Med. Microbiol. 6:207-212.

11. Love, D. N., J. L. Johnson, R. F. Jones, and A. Calverley. 1987. Bacteroides salivosus sp. nov., an asaccharolytic black-pigmented Bacteroides species from cats. Int. J. Syst. Bacteriol. 37:307-309.

12. Love, D. N., R. F. Jones, and M. Bailey. 1979. Clostridium villosum sp. nov. from subcutaneous abscesses in cats. Int. J. Syst. Bacteriol. 29:241-244.

13. Love, D. N., R. F. Jones, and A. Calverley. 1984. Asaccharolytic black-pigmented Bacteroides strains from soft-tissue infections in cats. Int. J. Syst. Bacteriol. 34:300-303.

14. Love, D. N., J. Karjalainen, A. Kanervo, B. Forsblom, E. Sarkiala, G. D. Bailey, D. I. Wigney, and H. Jousimies-Somer. 1994. Porphyromonas canoris sp. nov., an asaccharolytic black-pigmented species from gingival sulcus of dogs. Int. J. Syst. Bacteriol. 44:204-208.

15. Marmur, J., and P. Doty. 1962. Determination of base composition of deoxyribonucleic acid from its thermal denaturation temperature. J. Mol. Biol. 5:109-118.

16. Olsen, G. J., R. Overbeek, N. Larsen, T. L. Marsh, M. J. McCaughey, M. A. MacJukenas, W. M. Kuan, T. J. Macke, Y, Zing, and C. R. Woese. 1992. The Ribosomal Database Project. Nucleic Acids Res. 20:2199-2200.

17. Paster, B. J., F. E. Dewhirst, I. Olsen, and G. J. Fraser. 1994. Phylogeny of Bacteroides, Prevotella, and Porphyromonas spp. and related bacteria. J. Bacteriol. 176:725-732.

18. Richardson, B. J., P. R. Baverstock, and M. Adams. 1986. Allozyme electrophoresis. A handbook for animal systematics and population studies. Academic Press, Sydney, Australia.

19. Saitou, N., and M. Nei. 1987. The neighbor-joining method: a new method for reconstructing phylogenetic trees. Mol. Biol. Evol. 4:406-425.

20. Sarkiala, E. M., S. Asikainen, A. Kanervo, K. Jousimies, J. Karjalainen, B. Forsblom, and H. R. Jousimies-Somer. 1993. Antimicrobial susceptibility of Porphyromonas species in dogs with periodontitis. Abstr. Annu. Cong. Eur. Vet. Dent. Soc. Berlin.

21. Sarkiala, E. M., S. Asikainen, A. Kanervo, J. Junttila, and H. R. Jousimies-Somer. 1993. The efficacy of tinidazole in naturally occurring periodontitis in dogs: bacteriological and clinical results. Vet. Microbiol. 36:273-288.

22. Sarkiala, E. M., S. Asikainen, J. Wolf, A. Kanervo, I. Happonen, and H. Jousimies-Somer. 1993. Clinical, radiological and bacteriological findings of naturally occurring periodontitis in dogs. $\mathbf{J}$. Small Anim. Pract. 34:265-270.

23. Selin, Y. M., B. Harich, and J. L. Johnson. 1983. Preparation of labeled nucleic acids (nick translation and iodination) for DNA homology and rRNA hybridization experiments. Curr. Microbiol. 8:127-132.

24. Shah, H. N., and M. D. Collins. 1988. Proposal for reclassification of Bacteroides asaccharolyticus, Bacteroides gingivalis, and Bacteroides endodontalis in a new genus, Porphyromonas. Int. J. Syst. Bacteriol. 38:128-131.

25. Shah, H. N., and M. D. Collins. 1989. Proposal to restrict the genus Bacteroides Castellani and Chalmers to Bacteroides fragilis and closely related species. Int. J. Syst. Bacteriol. 39:85-87.

26. Shah, H. N., and R. A. D. Williams. 1982. Dehydrogenase patterns in the taxonomy of Bacteroides. J. Gen. Microbiol. 128:2955-2965.

27. Tereba, A., and B. J. McCarthy. 1973. Hybridization of ${ }^{125}$ I-labeled ribonucleic acid. Biochemistry 12:4675-4679. 